\title{
Conflict Resolution in the Perspectives
}

\author{
Andi Hartawati (Correspondence Author) \\ Sekolah Tinggi Ilmu Hukum Pengayoman, Makassar, Indonesia
}

Yusriadi Yusriadi

Sekolah Tinggi Ilmu Hukum Pengayoman, Makassar, Indonesia

\begin{abstract}
Received: June 23, 2019 Accepted: July 18, 2019 Online published: August 21, 2019
doi:10.5296/jpag.v9i3.14964ＵRL: https://doi.org/10.5296/jpag.v9i3.14964
\end{abstract}

\begin{abstract}
In a happy household, it based on the principle of mutual responsibility for the rights and obligations of husband and wife. But the reality is that families cannot always be calm and calm, sometimes there are conflicts in it. If the dispute not is resolved, it can lead to divorce. The increase in the number of cases that occur each year makes the writer formulate a problem, namely what is the cause of the conflict between husband and wife and how to resolve the dispute between husband and wife that affects the divorce. By adopting an empirical research approach, namely observing the symptoms of law in society. Causes of husband and wife conflicts such as value conflicts, lack of communication, ineffective leadership, incompatible roles, low productivity, changes in balance, problems not solved overcoming conflict by minimizing divorce making peace with religious observance, and increasing the value of local wisdom "Siri Na Pacce."
\end{abstract}

Keywords: conflict resolution, policy, perspective law, Indonesia

\section{Introduction}

Marriage is sacred so that it is expected to be maintained forever by husband and wife. But the reality of the life of a husband and wife in a household that sometimes experiences prolonged disputes and bickering. Peaked disputes between husband and wife can make the family not harmonious and can result in divorce. Divorce is the last resort a husband and wife can take if their household cannot be maintained anymore. The husband and wife dispute do not necessarily become the reason for breaking the marriage relationship, but it contains a process of mediation and reconciliation so that the household can be maintained.

The essence of marriage according to the Marriage Act No. 1 of 1974 in article 30 that the inner and outer bond between men and women as husband and wife aims to form a happy and 
eternal family based on the One Godhead. In living a married life as husband and wife need protection and affection. Here it means that a marriage is interdependent between husband and wife towards their partner, besides dependence in a relationship also requires a balance. Governments around the world build their institutions to achieve the stated goals and objectives (Yusriadi, 2018b).

In a relationship, balance is needed to maintain a marriage. Balance here is not always material; it can be attention, sacrifice, and division of tasks. If the balance not achieved, then the integrity of the relationship can be threatened to result in divorce (Lestatari, 2012). This research conducted to describe and analyze the causes of conflict between husband and wife and resolving disputes that have an impact on divorce in religious courts.

\section{Method}

This study uses empirical law because it is done by examining the legal phenomena that occur in the community and reviewing the implementation of conflict resolution between husband and wife which has an impact on divorce in the three Religious Courts and the Makassar Religious High Court in the South Sulawesi region.

\section{Results and Discussion}

\section{Factors causing conflict between husband and wife}

Every individual who carries out marriage aims to build a household. The absence of conflict does not mark the success of the marriage settlement, but families that can manage the conflict are approaching (Lestatari, 2012). Conflict as a symptom which undoubtedly found in every social life in all relationships, in community life, especially in the household, if the dispute is not resolved as early as possible with the right solution, it will create a far worse problem than before.

The occurrence of conflict in the household is a natural thing, and every married couple must understand and understand the causes of the conflict (Liliweri, 2005). The objectives of the conflict are as follows:

1. Value conflict is the basis, guideline, where every human being depends on thoughts, feelings, and actions. The model of conflict comes from differences in trust, confidence, even ideology over what contested.

2. Lack of Communication, failure of communicating between two parties cannot convey thoughts, feelings, and actions to open up the gap in information between them, resulting in conflict.

3. Leadership that is less effective, politically good leadership is robust, fair, and democratic leadership. Ineffective leadership results in community members being "easy to move."

4. Role Mismatch, this occurs because two parties perceive differently about their respective roles.

5. Low Productivity. Conflicts often occur because the outputs and outflows from two or 
more parties that are interconnected are less or do not benefit from the relationship, so prejudice arises between them. Economic disparity strongly supports the conflict.

6. Balance Change. This conflict occurs because there is a change in balance in a family; social factors more cause the cause.

7. Unsolved problem. Many conflicts occur in the family because of old issues that not resolved. There is no process of forgiving and forgiving each other so that it is like a fire in the husk, which at any time can flare up.

Marital conflict is a conflict involving a married couple where the battle has a significant effect or influence on the relationship between the two partners, the conflict arises because of the different perceptions, expectations and supported by the existence of their background, needs and values before deciding to bond (Sadarjoen, 2005), so marital conflict is a mental struggle between husband and wife caused by the existence of two individuals who have different views, temperaments, personalities, and values in looking at something and creating conflict as a result of the need, effort, desire or guidance from the outside in an inappropriate or contradictory. The first condition for efficient service delivery is they must genuinely know and understand how to provide satisfaction for the society (Umar et al., 2019).

A married couple consists of individuals who mostly have a variety of differences, both in terms of experience and needs. These differences are closely related to the values they profess that appear to play a role when they face and solve problems. Logically, the differences in interpreting something tend to trigger conflict if both partners are unable to find total agreement and are unable to accept differences (Sadarjoen, 2005).

Every couple has their hopes with their marriage. Hope between the two partners is difficult to develop at the beginning of the friendship because if one partner changes his expectations, then the other partner will maintain the previous expectations. Expectations that are not correctly interpreted by both partners will bring their partners to feel betrayed and hurt because they think unattended by their partners. One form of capacity building through the level of education as a form of formal education at certain levels of education, in assessing capacity building through formal education (Yusriadi, Sahid, Amirullah, Azis, \& Rachman, 2019).

There are four ways couples can resolve conflict in a marriage that is avoiding conflict, succumbing, discussion, and competence. Avoiding conflict is done where the couple raises behavior that can prevent them from ongoing conflict, by diverting conversations from the problems discussed (Meizara \& Basti, 2008). A woman's personality is an integrated unit between aspects of emotionality, ratio, and mood. The combined group has strong ties so that sometimes, it controls the thinking aspects of women, results in a woman as if thinking by including her feelings and mood (Gunarsah, 1991).

The following are the number of divorces in religious courts in the last three years in three cities in South Sulawesi as follows: 
Table 1. The number of divorces in the Palopo District Religious Court, Bone District Religious Court, and Religious Services in Makassar City

\begin{tabular}{|l|l|c|c|}
\hline No & \multicolumn{1}{|c|}{ City } & Year & Number of Divorces \\
\hline 1 & $\begin{array}{l}\text { Religious Court of Bone } \\
\text { Regency }\end{array}$ & 2016 & 309 \\
\hline & & 2017 & 349 \\
\hline 2 & $\begin{array}{l}\text { Religious Court of Palopo } \\
\text { Regency }\end{array}$ & 2018 & 285 \\
\hline & & 2015 & 183 \\
\hline 3 & $\begin{array}{l}\text { Religious Court of } \\
\text { Makassar City }\end{array}$ & 2017 & 225 \\
\hline & & 2016 & 199 \\
\hline & & 2017 & 623 \\
\hline
\end{tabular}

Based on the table above, it illustrates the magnitude of divorce cases in several religious courts in South Sulawesi every year, most of the reasons the wife filed for divorce because of many experienced disharmonies in domestic life. Through socialization campaigns, carried through direct and indirect means that way (Yusriadi, 2018a).

\section{Conflict resolution that impacts divorce}

Conflict resolution of husband and wife who want to divorce in a religious court-mediated in advance based on the Regulation of the Minister of Religion Number 1 of 2016 concerning the mediation procedure in the Court. Conflict resolution in the Islamic context is known as "ishlah." The word "ishlah" is now a standard term in the Indonesian language meaning peace or settlement of disputes (Bahasa, 2008).

Humans create rules and conditions for their needs for the sake of their kindness. Humans must be able to formulate ideas and values in social life, both personal and collective. Based on human creativity, wisdom is then born, which applies locally to internationally. Local wisdom in Islamic terminology is known as "al- urf" or "al-Adah" which means a good habit, which is accepted by reason, and the soul is calm towards it so that people recognize and practice it voluntarily (Al-Qurthubi, 1960).

On this side, local wisdom born in the form of ideas or values must always interpret sustainably following the progress of human behavior in society. The term will never change, but the meaning in it must continue to evolve to give birth to comprehensive goodness and as a good value that is interpreted from various aspects of life so that its usefulness can seen. In South Sulawesi culture (Bugis, Makassar, Tana Toraja) there is a term that reflects the identity and character of the people of South Sulawesi, especially the "Bugis-Makassar" tribe known as "siri' na pacce "culture. The language "Siri" means shame, while "Pacce" implies a kind of emotional intelligence to share the pain or distress of individuals in the community (solidarity and empathy) (Magfirah, 2016). 
Marriage does not involve men and women who marry only, but relatives of both parties to renew and strengthen their relationship. Marriage is the best way to include someone who is not a relative before. Marriage to the people of South Sulawesi Province is a sacred event and a cultural procession that shows pride in upholding the family honor. It also shows that a husband must be able to protect his wife in shipping her household, while his wife must be able to maintain her husband's dignity so that the family is the only purpose of life for married couples.

If the signs of shame are no longer on someone's face, such as wood that has been peeled off from its green skin, it is a sign that the virtue in someone has faded (Al-Gazali, 1995). The nature of shame is an integral part of faith because faith is one of the fruits and its main consequences. Muhammad Sallallahu 'alaihi wasallam said, "And shame is a part of faith" (Narrated by Abu Hurairah Radhiyallahu anhu). In another habits, the Prophet said: "Indeed, among the earlier prophetic words that are still remembered by the people is if you have no more shame, then do as you wish" (Narrated by Al-Bukhari).

The nature of shame is a noble character that is a feature of Islamic teachings. Prophet Muhammad said, "Indeed all religions have morals, and Islamic morality is a shame" (Narrated by Malik). Shame divided into three types, namely, first, a disgrace to Allah, both embarrassments to himself, and third to shame to fellow humans. The nature of shame is part of the morality taught in Islam. Therefore morality and primary behavior are an essential part of the existence of Islamic society. They are people who recognize the equality and justice, virtue, compassion, honesty, trust, patience, loyalty, shame, dignity, dignity, generosity, courage, struggle, sacrifice, cleanliness, beauty, simplicity, balance and mutual advise and work together (Qardhawy \& Susanti, 2003).

Muslims are encouraged to be patient by delaying their opinions from others, both Muslims and fellow non-Muslims. Patience is a good that Muslims must defend. Patience helps to maintain a strong faith in God. The word patience has meaning implications, 1) patients in doing work, careful, thorough, and not in a hurry; 2) Patience from perseverance, determination, steadfastness in trying to achieve goals; 3) Systematic and steadfast in opposing irregularities; and 4) Cheerful behavior when suffering (Yusuf, 1991).

Efforts to find conflict resolution from an Islamic perspective, which examined are primary sources (the Qur'an) and also the Prophet Muhammad. In the Qur'an, the concept of peace or conflict resolution does not directly use the term peace or conflict resolution. However, the message actualized in many verses that teach various individual and social piety (Taufiq, 2016), Elaboration of the concepts offered by the Qur'an to explore the spirit of the Qur'an relating to peace and conflict resolution.

The Qur'an as the highest source in Islam is very feasible to used as a reference in conducting conflict resolution, The Qur'an as an antidote, medicine, and solution to various problems, both psychological and social-religious issues of the community, including conflict issues, spirit of the relevant verses of the Qur'an used as inspiration for conflict resolution and the realization of peace. The Quran verse may not be a conflict resolution theory, but its content is referring to efforts that lead to conflict resolution and peace building (Mustaqim, 2014). 


\section{Conclusion}

Resolution of conflict in cases of divorce between husband and wife made with peace, and there are four ways couples can resolve disputes in marriage, namely avoiding conflict, succumbing, discussion, and competence. Avoiding conflict is done where the couple raises behaviour that can prevent them from ongoing conflict by diverting conversations from the problems discussed. Relent is done by one partner succumbing to their partner without resolving the conflict that occurred. The discussion conducted to find alternatives that could best satisfy the aspirations of the two parties. Competence of one partner will try so that his opinion used in resolving the conflict. On competence, one partner looks for mistakes or blames the partner, or it can also persuade/seduce the couple even by direct force so that in the end, the partner will yield. Solving family conflicts can use the Islamic approach known as peace, and the local wisdom approach in Sulawesi is known as the "Siri Na'pacce" culture.

\section{Reference}

Al-Gazali, M. (1995). Khuluqul Muslim, Akhlak Seorang Muslim, terj. Abu Laila dan Muhammad Tahir. Bandung: PT. Al' Ma'arif.

Al-Qurthubi, A. A. (1960). Al-Jami'al-Ahkam Al-Qur'an. Mesir: Dar al-Kutub.

Bahasa, P. (2008). Kamus Bahasa Indonesia. Jakarta: Departemen Pendidikan Nasional.

Gunarsah, S. D. (1991). Psikologi untuk muda-mudi. Jakarta.

Lestatari, S. (2012). Psikologi keluarga: penanaman nilai dan penanganan konflik dalam rumah tangga. Jakarta: Kencana Prenanda Group.

Liliweri, A. (2005). Prasangka dan Konflik: Komunikasi Lintas Budaya Masyarakat Multikultur. Yogyakarta: LKIS.

Magfirah, S. (2016). Siri’ Na Pacce Dalam Suku Makassar Perspektif Al-Qur‘An Dan Hadis. Tahdis, 7(2).

Meizara, P., \& Basti. (2008). Konflik Perkawinan dan Model Penyelesaian Konflik pada Pasangan suami istri. Jurnal Psikologi, 2(1).

Mustaqim, A. (2014). Konflik Teologis dan Kekerasan Agama dalam Kacamata Tafsir Al-Qurean. Jurnal Epitseme, 9(1). https://doi.org/10.21274/epis.2014.9.1.155-176

Qardhawy, Y., \& Susanti, R. (2003). Masyarakat Berbasis Syariat Islam, Akidah, Ibadah, Akhlak. Surakarta: Era Intermedia.

Sadarjoen, S. (2005). Konflik marital: Pemahaman konseptual, actual dan alternative solusinya. Bandung: Rafika Aditama.

Taufiq, I. (2016). Al-Qur"an Bukan Kitab Teror: Membangun Perdamaian Berbasis AlQur"an. Yogyakarta: Bentang Pustakan.

Umar, A., Amrin, Madani, M., Farida, U., Yusriadi, Tamsa, H., ... \& Misnawati. (2019). One-Stop Service Policy as A Bureaucratic Reform in Indonesia. Academy of Strategic 


\section{Macrothink Institute ${ }^{\mathrm{TM}}$}

Management

Journal,

https $/ /$ www.abacademies.org/articles/onesto onesia-8027.html

Yusriadi. (2018a). Bureaucratic Reform Barriers: A Case Study on the One Stop-Integrated Service Office in Bone Regency. Jurnal Kebijakan Dan Administrasi Publik, 22(2), 146-154. Retrieved from https://jurnal.ugm.ac.id/jkap/article/view/34536

Yusriadi. (2018b). Reformasi Birokrasi Indonesia: Peluang dan Hambatan. Jurnal Administrasi Publik (Public Administration Journal), 8(2), 178-185. https://doi.org/10.31289/jap.v8i2.1824

Yusriadi, S. A., Amirullah, I., Azis, A., \& Rachman, A. A. (2019). Bureaucratic Reform to the Human Resouces: A Case Study on the One-Stop Integrated Service. The Journal of Social Sciences Research. https://doi.org/10.32861/jssr.51.61.66

Yusuf, B. A. (1991). The Meaning of the Holy Qur'an. Brentwood: Amana Corporation.

\section{Copyright Disclaimer}

Copyright for this article is retained by the author(s), with first publication rights granted to the journal.

This is an open-access article distributed under the terms and conditions of the Creative Commons Attribution license (http://creativecommons.org/licenses/by/4.0/). 